\title{
The Influence of Entrepreneurship Knowledge, The Entrepreneurship, and Family Environment, Efficacy of Self, and Implications on The Interest Entrepreneurship (Survey at the Class XI State Brass Accounting)
}

\author{
Reni Martiani ${ }^{1}$, Iskandar ${ }^{2}$ \\ Kuningan University, Indonesia \\ Email : iskandar@uniku.ac.id
}

\begin{abstract}
The purpose of this research is to find knowledge, influence entrepreneurship attitude entrepreneurship, and family environment to efficacy and implications at interest entrepreneurship survey (students accounting class xi state brass). Type of correlational and this research is research methodology used is survey methods. Object research are state vocational high schools brass. In research study this population were students sample 106 and as many as 84 students calculated using formulas slovin. Sampling techniques used the random proportional sampling. And instrument used in this study is the type that uses scales survey Likert with five alternative answers. Data analysis technique analysis is the path. A subject in this study consisting of a variable free the entrepreneurship, $x 1$ (knowledge) entrepreneurship, the ( $\mathrm{x}$ ) family environment ( $\mathrm{x} 3$ ), efficacy to $\mathrm{z}(\mathrm{)})$ and variable interest bound the entrepreneurship ( he ).Based on testing statistics the results that knowledge, entrepreneurship, the family environment to efficacy and implications at interest to entrepreneurship of $\% 45,8$, and the rest of $\% 54,2$ affected other factors. Have concluded that hypothesis research received. In general conclusions from the test results applied in vocational brass show that knowledge, entrepreneurship, attitude a family environment impact on efficacy themselves and by implication at interest entrepreneurship. This study provides some limitation of the study and research agenda future that can be done to warrant further investigation
\end{abstract}

Keywords: knowledge; entrepreneurship; attitude a family environment; efficacy; selfentrepreneurship interest;

\section{Introduction}

Unemployment in Indonesia is currently the biggest problem that is difficult to overcome. This is due to the increasing number of job applicants compared to existing job fields. This condition will be exacerbated if each individual is only oriented as a job seeker, not a job creator. Many vocational high school graduates have focused on finding work, not creating jobs. They are more prepared to take part in recruitment selections than prepare to open new businesses. Indonesia is ranked fourth in the number of people in the world according to Pratiwi and Wardana (2016), stating that: "the density of the population in Indonesia causes competition for jobs to get tighter, causing a lot of unemployment". According to Pratiwi and Wardana (2016) states that: "one of the factors that causes the number of unemployed vocational high school 
graduates is a lack of awareness to create their own jobs". Therefore, according to Aggraeni and Nurcaya (2016), it is stated that: "entrepreneurship is one way to overcome the problem of the unemployment rate."

However, according to Anhari (2015: 98) states that: "Indonesia is still very lacking in entrepreneurs. Therefore, the entrepreneurial awareness of the Indonesian population still needs to be improved". According to Anhari (2015: 106) states that: "to become an entrepreneur, education and training are needed". Furthermore, according to Turker and Selcuk in Pratiwi and Wardana (2016) that: "the education offered by schools generally affects the choice of student work". According to Aritonang in Anggraeni and Nurcaya (2016) that: "entrepreneurship education aims to form individuals with character, skills, and understanding to become entrepreneurs".

Based on empirical data from the Central Statistics Agency (BPS), the latest data on the number of unemployed people as of February 2019, of the total working population of 129.36 million people, $40.51 \%$ have an elementary education level. The second largest portion is occupied by residents who have a high school education level (SMA), which is $17.86 \%$, while the lowest percentage is held by working residents who have a Diploma I / II / III education level, which is only $2.82 \%$ per February 2019 . University graduates also only account for $9.75 \%$ of the total working population in Indonesia. The open unemployment rate can be seen in the graph below:

Table 1. Table Open Unemployment Rate by Education as of February 2019

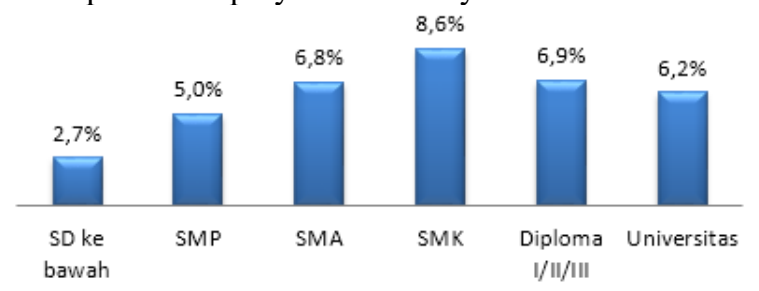

Based on the graphic table above, it shows that in terms of unemployment, it turns out that the largest TPT occurs in the population of graduates of Vocational High Schools (SMK), which reaches $8.6 \%$. Followed by TPT at the diploma level I / II / III and SMA, which were respectively $6.9 \%$ and $6.8 \%$. Meanwhile, the level of the University is also quite high, reaching $6.2 \%$. The results of the initial survey conducted by researchers indicated that there were three factors that had a dominant influence on the interest in entrepreneurship of vocational high school students, namely, entrepreneurial knowledge, entrepreneurial attitudes, family environment on self-efficacy.

According to Titik in Lestari, Hasiolan, and Minarsih (2016) that: "one of the factors driving a person to be entrepreneurial is The parental refugee which explains that many individuals get education and experience from businesses built by their families". The family environment greatly affects one's entrepreneurial interest. According to Campo in anggraeni and Nurcaya (2016) that: "Another factor that influences entrepreneurship is self-efficacy which is a person's confidence that he is able to successfully start a new business based on people's judgments about his ability to carry out certain activities. Therefore, based on this analysis, the researcher wanted to find out whether the entrepreneurial knowledge, family environment, and entrepreneurial attitude had a significant effect on self-efficacy and its implementation on the entrepreneurial interest of students of SMK Negeri Kuningan.

Thus the authors feel the need to conduct research by taking the title: "The Influence of Entrepreneurship Knowledge, Family Environment, and Entrepreneurial Attitudes affect Self 
Efficacy and its implications for Entrepreneurial Interest in Class XI Accounting Students at SMK Negeri Kuningan"

\section{Method}

In this study the authors used a survey research method with a quantitative approach. Because in this research is done by taking samples and using a questionnaire to get information from respondents. This statement is in accordance with the opinion expressed by Sugiyono (2003: 7) saying that: "Survey research is research that takes samples from the population using a questionnaire". While the type used in this research is descriptive and correlational. According to Indriantoro and Supomo (2002: 26) that: "Descriptive research (descriptive research) is a study of problems in the form of current facts from a population".

\subsection{Population and Sample}

Based on field research, the population in this study were 106 students of class XI Accounting at SMK Negeri Kuningan. Based on the Slovin formula above, the researchers took the following samples:

$$
\begin{aligned}
\mathrm{n} & =\frac{106}{1+106(5 \%)^{2}} \\
\mathrm{n} & =\frac{106}{1,256} \\
\mathrm{n}=84,39 & \text { set to } 84
\end{aligned}
$$

So thus the researchers determined the number of research samples, namely 84 people.

\subsection{Instrument Test}

\subsubsection{Validity test}

Validity is a measure that shows levels of validity or validity according to Suharsimi, (2010: 211) that: "an instrument is said to be valid if it is able to measure what is desired and can reveal data from the variables under study quickly". The level of validity of the instrument shows the extent to which the collected data does not deviate from the description of the variable in question.

Table 2. Results of the Validity Trial

\begin{tabular}{clccc}
\hline & Variable & \multicolumn{3}{c}{ Number of Questionnaires } \\
\cline { 3 - 5 } No & & $\begin{array}{c}\text { Invalid Before } \\
\text { Trial Valid }\end{array}$ & $\begin{array}{c}\text { Invalid Before } \\
\text { Trial Valid }\end{array}$ & $\begin{array}{c}\text { Invalid } \\
\text { Before Trial } \\
\text { Valid }\end{array}$ \\
\hline 1 & Entrepreneurial Knowledge (X1) & 12 & 12 & 0 \\
2 & Entrepreneurial Attitudes (X2) & 12 & 12 & 0 \\
3 & Family Ward (X3) & 15 & 15 & 0 \\
4 & Self-Efficacy (X4) & 12 & 12 & 0 \\
5 & Entrepreneurial Interest (Y) & 12 & 12 & 0 \\
\hline
\end{tabular}

\subsubsection{Reliability Test}

Apart from the instrument validity test. It is also necessary to calculate the reliability of the instrument. Research instruments that are considered good, apart from being valid, must also be reliable or have a value of accuracy. This calculation is related to the statement whether this 
research can be repeated or replicated by different researchers. According to Ghozali (2011: 47) that: "reliability is a tool to measure a questionnaire which is an indicator of a variable or construct". The results of the instrument reliability test are as follows:

Table 3. Results of the Validity Trial

\begin{tabular}{cccc}
\hline Variable & Cronbach Alpha & Limitation & Explanation \\
\hline X1 & 0,647 & 0,6 & Reliable \\
X2 & 0,768 & 0,6 & Reliable \\
X3 & 0,824 & 0,6 & Reliable \\
X4 & 0,775 & 0,6 & Reliable \\
Y & 0,901 & 0,6 & Reliable \\
\hline
\end{tabular}

\subsection{Data analysis method}

\subsubsection{Descriptive Analysis}

Before managing the data, the authors checked the respondents' questionnaire answers first, to check the number of questionnaires and the completeness of the answers.

\section{Normality test}

The data normality test is intended to determine the normal distribution of the sample data. The calculation to test whether or not the variable $\mathrm{X}$ is used is chi-square (X2) at an error rate equal to 0.05 with the following hypothesis:

$\mathrm{H} 0: \mathrm{X}$ is normally distributed

$\mathrm{H} 1: \mathrm{X}$ is not normally distributed

(Ating Somantri, 2006: 290)

If the distribution is normal, then the calculation is continued with parametric calculations and if the distribution is not normal, then the calculation will use non-parametric.

\subsubsection{Path Analysis}

Path analysis alone does not determine a causal relationship and also cannot be used as a substitute for researchers to see the causal relationship between variables that have been formed with a model based on theoretical grounds. What path analysis does is it determines the pattern of relationships between three or more variables and cannot be used to confirm or refute the imaginary causality hypothesis.

\section{Hypothesis testing}

Testf

Aim to find out the influence of the independent variables (X1, X2, X3 and X4) on the dependent variable (Y). The F-test is used as a test of the hypothesis test for the meaning of the regression model with the following formula:

$$
\mathrm{F}=(\mathrm{n}-\mathrm{k}-1) \mathrm{R}^{2} \mathrm{yxk}
$$

$$
\mathrm{K}\left(1-\mathrm{R}^{2}\right) \mathrm{Yxk}
$$

(Somantri, 2006: 314)

\section{T test}

To find the effect of each independent variable (entrepreneurial knowledge, entrepreneurial attitudes, and family environment) on the dependent variable (self-efficacy, entrepreneurial interest) partially used the test with the following formula:

$\mathrm{t}=\mathrm{rs} \sqrt{ }(\mathrm{n}-3)$

$1-\mathrm{rs} 2$

(Ating Somantri and Sambas Ali Muhidin, 2006: 233) 


\section{Result and Discussion}

Based on table 4, it can be seen from 84 students that the information about entrepreneurial knowledge variables is as follows: 16 students (19.04\%) have entrepreneurial knowledge in the high category, 54 students $(64.29 \%)$, have entrepreneurial knowledge in the medium category, and 14 students $(16.67 \%)$ have low entrepreneurial knowledge.

Table 4. Entrepreneurial Knowledge Variable Category X1

\begin{tabular}{clcc}
\hline Variable & Category & Frequency & Percentage (\%) \\
\hline X1 & High & 16 & 19,04 \\
& Moderate & 54 & 64,29 \\
& Low & 14 & 16,67 \\
& amount & $\mathbf{8 4}$ & $\mathbf{1 0 0}$ \\
\hline
\end{tabular}

Based on table 5, it can be seen from 84 students that the information about entrepreneurial attitude variables is obtained as follows: 9 students $(10.71 \%)$ have entrepreneurial attitudes in the high category, 70 students $(83.33 \%)$, have entrepreneurial knowledge in the medium category, and 5 students $(5.96 \%)$ have low entrepreneurial attitudes.

Table 5. Entrepreneurial Knowledge Variable Category X1

\begin{tabular}{clcc}
\hline Variable & Category & Frequency & Percentage (\%) \\
\hline $\mathbf{X 2}$ & High & 9 & 10,71 \\
& Moderate & 70 & 83,33 \\
& Low & 5 & 5,96 \\
\cline { 2 - 4 } & amount & $\mathbf{8 4}$ & $\mathbf{1 0 0}$ \\
\hline
\end{tabular}

Based on table 6 , it can be seen from 84 students that information about the family environment variables is as follows: 3 students $(3.57 \%)$ have a family environment in a good category, 66 students $(78.57 \%)$, have a family environment with a moderate category, and 15 students $(17.86 \%)$ have a bad family environment.

Table 6. Category of Family Environment Variables X3

\begin{tabular}{clcc}
\hline Variable & Category & Frequency & Percentage (\%) \\
\hline $\mathbf{X 3}$ & High & 3 & 3,57 \\
& Moderate & 66 & 78,57 \\
& Low & 15 & 17,86 \\
\cline { 2 - 4 } & amount & $\mathbf{8 4}$ & $\mathbf{1 0 0}$ \\
\hline
\end{tabular}

Based on table 7, it can be seen from 84 students that information about the self-efficacy variable is obtained as follows: 12 students (14.29\%) have high self-efficacy categories, 65 students $(77.38 \%)$, have moderate self-efficacy categories, and 7 students $(8.33 \%)$ had low selfefficacy.

Table 7. Category of Self Efficacy Variables X4

\begin{tabular}{clcc}
\hline Variable & Category & Frequency & Percentage (\%) \\
\hline $\mathbf{X 4}$ & High & 12 & 14,29 \\
& Moderate & 65 & 77,38 \\
& Low & 7 & 8,33 \\
\cline { 2 - 4 } & amount & $\mathbf{8 4}$ & $\mathbf{1 0 0}$ \\
\hline
\end{tabular}

Based on table 8 , it can be seen from 84 students that information about the variable interest in entrepreneurship is obtained as follows: 10 students $(11.91 \%)$ have high entrepreneurial 
interest, 66 students $(78.57 \%)$, have moderate interest in entrepreneurship, and 8 students $(9.52 \%)$ have low interest in entrepreneurship.

Table 8. Entrepreneurial Interest Variable Category Y

\begin{tabular}{clcc}
\hline Variable & Category & Frequency & Percentage (\%) \\
\hline $\mathbf{Y}$ & High & 10 & 11,91 \\
& Moderate & 66 & 78,57 \\
& Low & 8 & 9,52 \\
\cline { 2 - 4 } & amount & $\mathbf{8 4}$ & $\mathbf{1 0 0}$ \\
\hline
\end{tabular}

\section{Normality test}

Table 9. Normality Test Using One-Sample Kolmogorov-Smirnov Test

\begin{tabular}{|c|c|c|c|c|}
\hline $\begin{array}{l}\text { knowledge of } \\
\text { Entrepreneurship }\end{array}$ & $\begin{array}{c}\text { Entrepreneurial } \\
\text { Attitudes, }\end{array}$ & $\begin{array}{l}\text { Family } \\
\text { Environment }\end{array}$ & $\begin{array}{l}\text { Efficacy } \\
\text { Self }\end{array}$ & $\begin{array}{l}\text { Interest in } \\
\text { Entrepreneurship }\end{array}$ \\
\hline 84 & 84 & 84 & 84 & 84 \\
\hline 7.05 & 37.56 & 44.14 & 39.36 & 37.25 \\
\hline 2.439 & 5.520 & 7.706 & 5.834 & 6.248 \\
\hline .159 & .086 & .111 & .188 & .134 \\
\hline .158 & .086 & .085 & .092 & .091 \\
\hline-.159 & -.075 & -.111 & -.188 & -.134 \\
\hline 1.156 & .786 & 1.016 & 1.226 & 1.229 \\
\hline .169 & .567 & .253 & .105 & .097 \\
\hline
\end{tabular}

Asymp. Sig. (2-tailed)

.169

.567

097

a. Test distribution is Normal.

b. Calculated from data.

a. X1 Normality Test (Entrepreneurial Knowledge)

Based on the table, in the Entrepreneurial Knowledge variable column the KolmogrovSmirnovZ value is 1,156 with a probability (Asymp. Sig. (2-tailed)) of 0.169 . The data requirement is called normal if the probability value or $p>0.05$. Because the $p$ value $>0.05$ or $0.169>0.05$, the data for the Quality of Entrepreneurial Knowledge variable is normal or meets the requirements of the normality test.

b. X2 Normality Test (Entrepreneurial Attitudes)

Based on the table, the Kolmogrov-SmirnovZ variable column obtained the value of 0.786 with a probability (Asymp. Sig. (2-tailed)) of 0.567. The data requirement is called normal if the probability value or $p>0.05$. Because the $p$ value $>0.05$ or $0.567>0.05$, the entrepreneurial attitude variable data is normal or meets the normality test requirements.

c. 3. X3 Normality Test (Family Environment)

Based on the table, in the Family Environment variable column the Kolmogrov-SmirnovZ value is 1.016 with a probability (Asymp. Sig. (2-tailed)) of 0.253 . The data requirement is called normal if the probability value or $p>0.05$. Because the $p$ value $>0.05$ or $0.253>0.05$, the family environment variable data is normal or meets the normality test requirements.

d. 4. X4 Normality Test (Self Efficacy)

Based on the table, the Kolmogrov-SmirnovZ variable column obtained the value of 1.226 with a probability (Asymp. Sig. (2-tailed)) of 0.105 . The data requirement is called normal if the probability value or $p>0.05$. Because the $p$ value $>0.05$ or $0.105>0.05$, the data for the Self Efficacy variable is normal or meets the requirements of the normality test. 
e. Normality Test Y (Entrepreneurial Interest)

Based on the table, in the Entrepreneurial Interest variable column the Kolmogrov-SmirnovZ value is 1,229 with a probability (Asymp. Sig. (2-tailed)) of 0.097 . The data requirement is called normal if the probability value or $p>0.05$. Because the $p$ value $>0.05$ or $0.097>0.05$, the data for the Entrepreneurial Interest variable is normal or meets the requirements of the normality test.

\section{Multicollinearity Test}

Table 10. Multicollinearity Test Results Coefficients Coefficients

\begin{tabular}{lllr}
\hline \multirow{2}{*}{ Model } & \multicolumn{3}{c}{ Collinearity Statistics } \\
\cline { 2 - 4 } 1 & Entrepreneurial Knowledge & Tolerance & VIF \\
\cline { 2 - 4 } & Entrepreneurial Attitude & .796 & 1.257 \\
\cline { 2 - 4 } & Family environment & .646 & 1.547 \\
\cline { 2 - 4 } & Self-Efficacy & .681 & 1.468 \\
\hline
\end{tabular}

a. Dependent Variable: Entrepreneurial Interests

From the results of the table above, it is known that the value of the Variance Inflation Factor (VIF) for the four variables, namely Entrepreneurial Knowledge $(1,257)$, Entrepreneurial Attitude (1,547), Family Environment $(1,468)$ and Self-Efficacy $(1,627)$, is smaller than 5, so it can be assumed that the independent variable is not Multicollinearity problem occurs.

\section{Autocorrelation Test}

Table 11. Autocorrelation Test Results Model Summary b

\begin{tabular}{|c|c|c|c|c|c|}
\hline Model & $\mathrm{R}$ & R Square & Adjusted R Square & $\begin{array}{l}\text { Std. Error of the } \\
\text { Estimate }\end{array}$ & $\begin{array}{l}\text { Durbin- } \\
\text { Watson }\end{array}$ \\
\hline 1 & $.677^{\mathrm{a}}$ & .458 & .431 & 4.715 & 2.113 \\
\hline
\end{tabular}

It can be seen from the results of calculations using the SPSS for Windows Version 21 program. The $\mathrm{DW}$ value is 2.113 . The result of $\mathrm{DW}=2.113$ if it is adjusted to the classification table of the $\mathrm{D}-\mathrm{W}$ value, then the value lies between $1.55-2.46$; which indicates that there is no autocorrelation.

\subsection{Research Data Analysis \\ Hypothesis Testing and Path Analysis}

a. Path Coefficients X1, X2, X3 with respect to X4

Based on the results of the path coefficient calculation above, it is known that the correlation coefficient for the Entrepreneurial Knowledge variable (X1) is 0, 549 and the t-test statistical test results for $\mathrm{t} 2 \mathrm{x} 1=2.308$ with sig. 0.024 , the entrepreneurial attitude variable $(\mathrm{X} 2)$ is 0.270 and the results of the t-test statistic for $\mathrm{t} \times 2 \times 1=2.316$ with sig. 0.023 , the family environment variable (X3) is 0,257 and the results of the t-test statistic for $\mathrm{tx} 2 \mathrm{x} 1=2.559$ with sig. 0.012 , the variable Self Efficacy (X4) is 0.223 and the results of the t-test statistical test for $\mathrm{tx} 2 \mathrm{x} 1=2.109$ with sig. 0.038 . Based on table $4: 16$, the following results are obtained: 


\section{Path Coefficient X1 to Y}

The magnitude of the influence of X1 on $\mathrm{Y}(\rho \mathrm{x} 1)$ is 0.214 or $(0.214) 2 \times 100 \%=0.046 \times 100 \%$ $=4.6 \%$. The $\mathrm{t}$ test for the effect of $\mathrm{X} 1$ on $\mathrm{Y}$ obtained the value of tcount $=2.308$ with a significance $=0.024$. Because the significance value $=0.024<$ alpha $=0.05$, there is a positive effect of $\mathrm{X} 1$ on $\mathrm{Y}$.The magnitude of the influence of X1 on Y through X4 $(\rho \mathrm{Yx} 4 \mathrm{x} 1)$ is $\rho \mathrm{x} 4 \mathrm{x} 1 \mathrm{x}$ pyx $4=0.335 \times 0.223=0.075$ or $0.075 \times 100 \%=7,5 \%$. The $t$ test for the effect of $\mathrm{X} 1$ on $\mathrm{X} 4$ obtained a significance value of 0.000 and the $t$ test for the effect of $\mathrm{X} 4$ on $\mathrm{Y}$ obtained a significance value of 0.038 . Because the two significance values $<$ alpha $=0.05$, there is an effect of variable $\mathrm{X} 1$ on variable $\mathrm{X} 4$ and its implementation in variable $\mathrm{Y}$.

\section{Path Coefficient X2 to Y}

The magnitude of the influence of X2 on Y ( $\rho y \times 2)$ is 0.239 or $(0.239) 2 \times 100 \%=0.057 \times 100 \%$ $=5.7 \%$. The $\mathrm{t}$ test for the effect of $\mathrm{X} 2$ on $\mathrm{Y}$ obtained the value of $\mathrm{t}$ count $=2.316$ with a significance $=0.023$. Because the significance value $=0.023<$ alpha $=0.05$, there is a positive effect of X2 on Y. The magnitude of the influence of X2 on Y through X4 $(\rho Y x 4 x 2)$ is $\rho X 4 x 2$ $\mathrm{x} \rho \mathrm{Yx} 4=0.261 \times 0.223=0.058$ or $0.058 \times 100 \%=5,8 \%$. The $\mathrm{t}$ test for the effect of $\mathrm{X} 2$ on $\mathrm{X} 4$ obtained a significance value of 0.015 and the $t$ test for the effect of $\mathrm{X} 4$ on $\mathrm{Y}$ obtained a significance value of 0.038 . Because the two significance values $<$ alpha $=0.05$, there is an effect of variable $\mathrm{X} 2$ on variable $\mathrm{X} 4$ and its implementation in variable $\mathrm{Y}$.

\section{Path Coefficient X3 to Y}

The magnitude of the influence of X3 on Y ( $\rho y \times 3)$ is 0.257 or $(0.257) 2 \times 100 \%=0.066 \times 100 \%$ $=6.6 \%$. The $\mathrm{t}$ test for the effect of $\mathrm{X} 3$ on $\mathrm{Y}$ obtained the value of tcount $=2.559$ with a significance $=0.012$. Because the significance value $=0.012<$ alpha $=0.05$, there is a positive effect of $\mathrm{X} 3$ on $\mathrm{Y}$. The magnitude of the influence of $\mathrm{X} 3$ on $\mathrm{Y}$ through $\mathrm{X} 4(\rho \mathrm{Yx} 4 \mathrm{x} 3)$ is $\rho \mathrm{x} 4 \mathrm{x} 3 \mathrm{x}$ pyx $4=0.269 \times 0.223=0.060$ or $0.060 \times 100 \%=6,0 \%$. The $t$ test for the effect of $\mathrm{X} 3$ on $\mathrm{X} 4$ is obtained significance of 0.010 and t test for the effect of $\mathrm{X} 4$ on $\mathrm{Y}$ obtained a significance value of 0.038 . Because the two significance values $<$ alpha $=0.05$, there is an effect of variable $\mathrm{X} 3$ on variable $\mathrm{X} 4$ and its implementation in variable $\mathrm{Y}$.

\section{Path Coefficient of X4 to Y}

The magnitude of the influence of $\mathrm{X} 4$ on $\mathrm{Y}(\rho \mathrm{Yx} 4)$ is 0.223 or $(0.223) 2 \times 100 \%=0.050 \mathrm{x}$ $100 \%=5.0 \%$. The $t$ test for the effect of $\mathrm{X} 4$ on $\mathrm{Y}$ obtained the value of $\mathrm{t}$ count $=2.109$ with a significance $=0.038$. Because the significance value $=0.038<$ alpha $=0.05$, there is a positive effect of $\mathrm{X} 4$ on $\mathrm{Y}$.

If the value of the Structural Model is 2

$\mathrm{Y}=\rho \mathrm{yx} 1 . \mathrm{X} 1+\rho \mathrm{yx} 2 . \mathrm{X} 2+\rho \mathrm{yx} 3 . \mathrm{X} 3+\rho \mathrm{yx} 4 . \mathrm{X} 4+\varepsilon 2$

$\mathrm{Y}=0.214 \mathrm{X} 1+0.239 \mathrm{X} 2+0.257 \mathrm{X} 3+0.223 \mathrm{X} 4+0.736$

Substituted to a path diagram, it can be described as follows: 


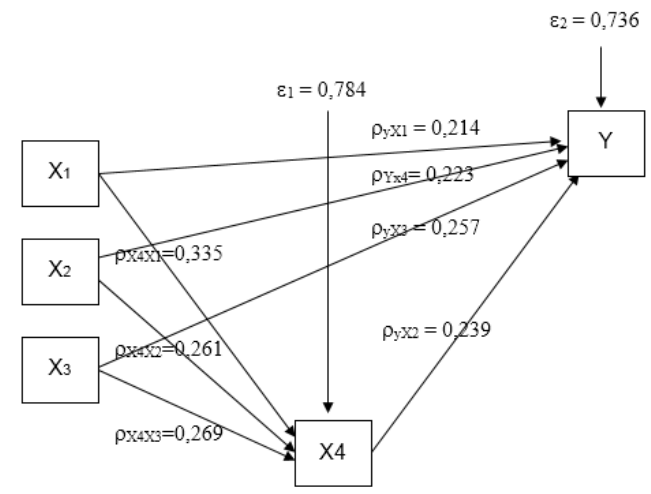

Fig 1. Complete Path Diagram to (Variable Y)

Based on the path diagram above, it can be concluded that variable X1, variable X2, variable $\mathrm{X} 3$, and variable $\mathrm{X} 4$ have an effect on variable $\mathrm{Y}$ is declared acceptable.

\section{The Influence of Entrepreneurial Knowledge on Self-Efficacy}

Based on the results of the analysis, entrepreneurial knowledge has a significant effect on self-efficacy with the magnitude of the effect of X1 on X4 ( $\square \mathrm{X} 4 \mathrm{X} 1)$, namely 0.335 or (0.335) 2 $\mathrm{x} 100 \%=0.112 \times 100 \%=11.2 \%$. The $\mathrm{t}$ test for the effect of X1 on X4 obtained the value of tcount $=3.683$ with a significance $=0.000$. Because the significance value $=0.000<$ alpha $=$ 0.05 , there is a positive effect of $\mathrm{X} 1$ on $\mathrm{X} 4$. Thus it can be said that if entrepreneurial knowledge is high, it will have a significant effect on self-efficacy. In line with the theory put forward by Alma, (2014) that: "Entrepreneurial knowledge aims to shape human beings as a whole, as people who have character, understanding and skills as entrepreneurs.

After looking at the theory and results in the field, it can be said that entrepreneurial knowledge has an effect on self-efficacy. The higher or the better the knowledge of entrepreneurship, the self-efficacy will increase. So it can be concluded that the results of the research carried out are in line with prevailing theories and principles. In addition, the results of this study are also in synergy with findings in previous research conducted by Wahyudin, Agus (2018). "The influence of the family environment, entrepreneurial knowledge, personality and motivation, on the interest in entrepreneurship with self-efficacy as a moderating variable." The results of the study can be explained as follows: The result of the magnitude of the $\mathrm{R}$ square value is 0.446 . This means that $44.6 \%$ of the variable interest in entrepreneurship can be explained by the variance of the independent variables, namely the family environment, entrepreneurial knowledge, personality, and motivation as well as the interaction of the family environment with self-efficacy.

\section{The Influence of Entrepreneurial Attitudes on Self-Efficacy}

Based on the results of the analysis, entrepreneurial attitudes have a significant effect on self-efficacy with the magnitude of the influence of X2 on X4 ( $\rho X 4 \times 2)$, namely 0.261 or $(0.261)$ $2 \times 100 \%=0.068 \times 100 \%=6.8 \%$. The $t$ test for the effect of X2 on X4 obtained the value of tcount $=2.489$ with a significance $=0.015$. Because the significance value $=0.015<$ alpha $=$ 0.05 , there is a positive effect of X2 on X4. Thus it can be said that if the entrepreneurial attitude is high, it has a significant effect on self-efficacy. In line with the theory put forward by Purnomo, (2005) that: "entrepreneurial attitude is a picture of a person's personality who is born through physical movements and the response of one's thoughts to the entrepreneurial aspect". 
After looking at the theory and results in the field, it can be said that entrepreneurial attitudes have an effect on self-efficacy. The higher or the better the entrepreneurial attitude, the selfefficacy will increase. So it can be concluded that the results of the research carried out are in line with the prevailing theories and principles. In addition, the results of this study are also in synergy with findings in previous research conducted by Agung, Artha (2016), "the influence of entrepreneurial attitudes, education and the family environment on interest in entrepreneurship with self-efficacy as a moderating variable. The results of the analysis of the influence of entrepreneurial attitudes on interest in entrepreneurship obtained a sig t value of 0.004 with a beta coefficient of 0216 . A sig $t$ value of $0.004<0.05$ indicates that Ho is rejected and $\mathrm{H} 1$ is accepted.

\section{The Effect of Family Environment on Self Efficacy}

Based on the results of the analysis, the family environment has a significant effect on selfefficacy with the magnitude of the influence of X3 on X4 ( $\rho$ X4x3), namely 0.269 or $(0.269) 2$ $\mathrm{x} 100 \%=0.072 \times 100 \%=7.2 \%$. The $t$ test for the effect of X3 on X4 obtained the value of tcount $=2.645$ with a significance $=0.010$. Because the significance value $=0.010<$ alpha $=$ 0.05 , there is a positive effect of $\mathrm{X} 3$ on $\mathrm{X} 4$. Thus it can be said that if the family environment is high, it has a significant effect on self-efficacy. In line with the theory put forward by Koranti (2013) states that: "the family environment with all the conditions that exist in it including the background of family members, family traditions and how parents educate will be able to support, guide and encourage someone, especially students for the future life".

After looking at the theory and results in the field, it can be said that the family environment affects self-efficacy. The higher or the better the entrepreneurial attitude, the self-efficacy will increase. So it can be concluded that the results of the research carried out are in line with the prevailing theories and principles. In addition, the results of this study are also in synergy with findings in previous research conducted by Wahyudin, Agus (2018). "The influence of the family environment, entrepreneurial knowledge, personality and motivation, on the interest in entrepreneurship with self-efficacy as a moderating variable." The results of the study can be explained as follows: The result of the magnitude of the $\mathrm{R}$ square value is 0.446 . This means that $44.6 \%$ of the variable interest in entrepreneurship can be explained by the variance of the independent variables, namely the family environment, entrepreneurial knowledge, personality, and motivation as well as the interaction of the family environment with self-efficacy.

\section{The Influence of Entrepreneurial Knowledge on Entrepreneurial Interest}

Based on the analysis results, entrepreneurial knowledge has a significant effect on interest in entrepreneurship with the magnitude of the influence of X1 on Y ( $(0.214) 2 \times 100 \%=0.046 \times 100 \%=4.6 \%$. The $t$ test for the effect of X1 on Y obtained the value of tcount $=2.308$ with a significance $=0.024$. Because the significance value $=0.024<$ alpha $=$ 0.05 , there is a positive effect of X1 on Y. Thus it can be said that if entrepreneurial knowledge is high, it will have a significant effect on interest in entrepreneurship. In line with the theory put forward by Alma, (2014) that: "Entrepreneurial knowledge aims to shape human beings as a whole, as people who have character, understanding and skills as entrepreneurs. Many entrepreneurial expertise and skills are obtained from entrepreneurial knowledge. Give students the inculcation of behavioral attitudes to open a business and then we will make them talented entrepreneurs".

After looking at the theory and results in the field, it can be said that entrepreneurial knowledge has an effect on entrepreneurial interest. The higher or better the knowledge of entrepreneurship, the interest in entrepreneurship will increase. So it can be concluded that the 
results of the research carried out are in line with the prevailing theories and principles. In addition, the results of this study are also in synergy with the findings in previous research conducted by Harini (2018), "the influence of entrepreneurial knowledge and self-efficacy on entrepreneurial interest (studies on students of economic education study programs in the 20142016 class) f obtained $f$ count of 12,569 and $f$ table 3.07. This shows that $f$ count $>f$ table. The probability value in the sig $<0.05$ column is 0.000 , so it can be concluded that Ho is rejected and $\mathrm{Ha}$ is accepted.

\section{The Influence of Entrepreneurial Attitudes on Entrepreneurial Interest}

Based on the analysis, entrepreneurial attitudes have a significant effect on interest in entrepreneurship with the magnitude of the influence of X2 on Y ( $(0.239) 2 \times 100 \%=0.057 \times 100 \%=5.7 \%$. The $t$ test for the effect of X2 on Y obtained the value of $\mathrm{t}$ count $=2.316$ with a significance $=0.023$. Because the significance value $=0.023<$ alpha $=$ 0.05 , there is a positive effect of $\mathrm{X} 2$ on $\mathrm{Y}$. Thus it can be said that if the entrepreneurial attitude is high, it will significantly influence the interest in entrepreneurship. In line with the theory put forward by Widaryanti (2013), that: "Attitude is an organization of daily beliefs about objects and situations while entrepreneurship is the result of a disciplined and systematic process of applying creativity and innovation to market needs and opportunities (Zimmer et al., 2008), entrepreneurial attitude is a description of the personality of a person who is born through physical movements and the response of one's thoughts to entrepreneurial aspects (Purnomo, 2005).

After looking at the theory and results in the field, it can be said that entrepreneurial attitudes affect entrepreneurial interest. The higher or the better the entrepreneurial attitude, the interest in entrepreneurship will increase. So it can be concluded that the results of the research carried out are in line with the prevailing theories and principles. In addition, the results of this study are also in synergy with the findings in previous research conducted by Vendy (2017) "The Effect of Entrepreneurship Education, attitude on Entrepreneurial Intention of University Students by Adopting Linan Model" based on some hypotheses conducted, it describes the result that $\mathrm{H} 1$ is accepted. It confirms that the entrepreneur has a positive effect on the entrepreneurial intention with the pvalue (a) $=0,000$. Meanwhile, H2a for testing the influence of the entrepreneur knowledge on personnel attitude is accepted with the $p$-value $(a)=0,000$ proves there is the positive influence of entrepreneur knowledge on social norms.

\section{The Effect of Family Environment on Entrepreneurial Interest}

Based on the results of the analysis, the family environment has a significant effect on interest in entrepreneurship with the amount of influence X3 on Y ( $\rho y x 3)$, namely 0.257 or $(0.257) 2 \times 100 \%=0.066 \times 100 \%=6.6 \%$. The $t$ test for the effect of X3 on Y obtained the value of tcount $=2.559$ with a significance $=0.012$. Because the significance value $=0.012<$ alpha $=$ 0.05 , there is a positive effect of $\mathrm{X} 3$ on $\mathrm{Y}$. Thus it can be said that if the family environment is high, it will have a significant effect on interest in entrepreneurship. In line with the theory put forward by Saroni (2012) states that: "the family environment has a very big role in preparing children to become entrepreneurs in the future". After looking at the theory and results in the field, it can be said that the family environment affects the interest in entrepreneurship. The higher or the better the entrepreneurial attitude, the interest in entrepreneurship will increase.

So it can be concluded that the results of the research carried out are in line with the prevailing theories and principles. In addition, the results of this study are also in synergy with the findings in previous research conducted by Ni Made, Sintya (2019) "The Influence of SelfEfficacy Motivation, Income Expectations, Family Environment, and Entrepreneurship 
Education, on Entrepreneurial Interest in Accounting Department Students at Mahasarawati University Denpasar." From the research it is known that the indicators on each variable in this study are valid and suitable to be used to conduct research or test the research hypothesis because the Pearson correlation value for each question item is greater than 0.30 and sign 2 is less than 0.05 .

\section{The Effect of Self-Efficacy on Entrepreneurial Interest}

Based on the analysis, self-efficacy has a significant effect on interest in entrepreneurship with the magnitude of the influence of X4 on Y $(\rho Y x 4)$, namely 0.223 or $(0.223) 2 \times 100 \%=$ $0.050 \times 100 \%=5.0 \%$. The $t$ test for the effect of $\mathrm{X} 4$ on $\mathrm{Y}$ obtained the value of $\mathrm{t}$ count $=2.109$ with a significance $=0.038$. Because the significance value $=0.038<$ alpha $=0.05$, there is a positive effect of $\mathrm{X} 4$ on $\mathrm{Y}$. Thus it can be said that if self-efficacy is high, it will have a significant effect on interest in entrepreneurship. In line with the theory put forward by Bandura (in Jess Feist, 2010: 212) Self Efficacy: "is a person's belief in his ability to exercise some form of control over one's own functions and events in the environment". Bandura also described Self Efficacy as a determinant of how people think, motivate themselves, and behave (Bandura, 1994: 2).

According to Schunk (Anwar, 2009: 23) states that: "self-efficacy is very important in influencing the business undertaken, how strong the effort is in predicting the success achieved". This is in line with what Woolfolk stated (Anwar, 2009: 23) that: "self-efficacy is a person's assessment of himself or the level of confidence regarding how much he is able to do a certain task to achieve certain results'. After looking at the theory and results in the field, it can be said that self-efficacy affects the interest in entrepreneurship. The higher or better self-efficacy, the interest in entrepreneurship will increase. So it can be concluded that the results of the research carried out are in line with the prevailing theories and principles.

In addition, the results of this study are also in synergy with findings in previous research conducted by Wahyudin, Agus (2018). "The influence of the family environment, entrepreneurial knowledge, personality and motivation, on the interest in entrepreneurship with self-efficacy as a moderating variable." The results of the study can be explained as follows: The result of the magnitude of the $\mathrm{R}$ square value is 0.446 . This means that $44.6 \%$ of the variable interest in entrepreneurship can be explained by the variance of the independent variables, namely the family environment, entrepreneurial knowledge, personality, and motivation as well as the interaction of the family environment with self-efficacy. In other words, the results of this study indicate a positive influence together between entrepreneurial knowledge, entrepreneurial attitudes, and family environment on self-efficacy and its implications for entrepreneurial interest. Therefore, students must continue to improve entrepreneurial knowledge, entrepreneurial attitudes, and the family environment towards self-efficacy in order to be able to increase their interest in entrepreneurship.

\section{Conclusion}

As the final stage of writing this thesis, the following authors present some conclusions from the research that has been carried out as follows:

a. Entrepreneurial knowledge has a positive effect on self-efficacy. This means that if entrepreneurial knowledge is high, self-efficacy will increase. 
b. Entrepreneurial attitude has a positive effect on self-efficacy. This means that if the entrepreneurial attitude is positive, self-efficacy will increase.

c. Family environment has a positive effect on self-efficacy. This means that if the family environment is conducive, self-efficacy will increase.

d. Entrepreneurial knowledge has a positive effect on interest in entrepreneurship. This means that if entrepreneurial knowledge is high, interest in entrepreneurship will increase.

e. Entrepreneurial attitudes have a positive effect on interest in entrepreneurship. This means that if the entrepreneurial attitude is positive, the interest in entrepreneurship will increase.

f. Family environment has a positive effect on interest in entrepreneurship. This means that if the family environment is conducive, interest in entrepreneurship will increase.

g. Self-efficacy has a positive effect on interest in entrepreneurship. This means that if selfefficacy is high, interest in entrepreneurship will increase.

\section{References}

[1] Alwisol. 2009. Personality Psychology. Malang: UMM Press.

[2] Alma. 2014. Marketing Management and Services Marketing. Bnadung: Alfabeta Publisher.

[3] Anhari. 2015. Smart Book on Managing Finances for a Better Life. Yogyakarta: Kobis.

[4] Arikunto, Suharsimi. 2006. Research Procedure A Practical Approach. Jakarta: PT Rineka Cipta.

[5] Anggraeni and Nurcaya. 2016. The Role of Efficacy in Mediating the Effect of Entrepreneurship Education on Entrepreneurial Intentions. Management E-journal of Udayana University.

[6] Anwar. 2009. Human Resource Management. Bandung: PT. Youth of Kosda Karya.

[7] Bandura, Albert. 1997. Self Efficacy. The Exerices of Control New York: W.H.Freman and Company.

[8] Central Bureau of Statistics. 2019. Open Unemployment Rate (TPT). Accessed from https://www.bps.go.id on February 28, 2019.

[9] Djaali. 2008. Educational Psychology. Jakarta: Earth Literacy.

[10] Ghozali, Imam. 2011. Multivariate Analysis Application with SPSS Program. Semarang: Diponegoro University Publishing Agency.

[11] Guruvalah. 2003. Income Level Head of family. Jakarta.

[12] Hamalik, Oemar. 1983. Learning Methods and Learning Difficulties. Bandung: Tarsito.

[13] Handayaningrat. 1992. Introduction to Administrative and Management Science Studies. Jakarta: Cv Hajimasagung.

[14] Hendro. 2010. Basics of Entrepreneurship A Guide for Students to Know, understand, and enter the world of business. Jakarta: Erlangga Publisher.

[15] Indriantoro, Nur \& Supomo, Bambang. 2002. Business Research Methodology. Yogyakarta: BPFE.

[16] Indrianto, Nur \& Supomo, Bambang. 1999. Business Research Methodology. Yogyakarta: BPFE Yogyakarta.

[17] Kartono, K. 1992. Tutoring in High School and Higher Education. Jakarta: Raja Grafindo Persada.

[18] Komarrudin. 1983. Marketing Management Consumer Behavior Analysis. Bandung: Space.

[19] Koranti. 2013. Human Behavior. Jakarta. Isbn.

[20] Kotler, Philip. 2002. Marketing Management Indonesian Edition Volume 1. Jakarta: PT. Gramedia Group Index.

[21] Loekmono. 1994. Learning How to Learn. Jakarta: BPK Gunung Mulia.

[22] Mcclelland, David. 1961. Entrepreneur Behavior And Characteristic of Entrepreneurs. The Achieving Society.

[23] Meredith. 2000. Entrepreneurship Theory and Practice. Jakarta: PT. Pustaka Binaman Pressindo.

[24] Miraza. 2008. Entrepreneurship. Jakarta: Four Salemba.

[25] Moenir. 2001. Public Service Management in Indonesia. Jakarta: Bumi Aksara.

[26] Robbin. 2008. Organizational Behavior. Jakarta: Index. 
[27] Robinshon. 1991. The EAO Model. ITB Press: Bandung.

[28] Saroni. 2012. Educating and training young entrepreneurs. Yogyakarta: Ar-ruzz Media.

[29] Slameto. 2003. Learning and the factors that influence it. Jakarta: PT. Rineka Cipta.

[30] Slameto. 2013. Learning and the factors that influence it. Jakarta: PT. Rineka Cipta.

[31] Somantri, Ating. 2011. Basics of Statistical Methods for Research. Bandung: Faithful Library.

[32] Somantri, Ating \& Sambas Ali Muhidin, S.Pd. 2006. Applications of Statistics in Research. Bandung: CV. Faithful Library.

[33] Sudjana. 1997. Statistics for Research. Jakarta: PT Gramedia.

[34] Suharsaputra, Uhar. 2011. Research Methods. Kuningan: House of Books.

[35] Sugiyono. 2012. Statistics for Research, Bandung: Alfabeta.

[36] Sujanto, Agus. 1986. General Psychology. Jakarta: PT. Rineka Cipta.

[37] Sukardi. 2001. Entrepreneurial Personality. Jakarta. Earth Literacy.

[38] Sukardi. 1987. Guidance and Outreach. Surabaya: National Business.

[39]

[40] Sumarsono. 2010. Entrepreneurship. Yogyakarta: Graha Science.

[41] Surachman, Winarmo. 1994. Introduction to Scientific Research, Basic Methods and Techniques. Bandung: Tarsito.

[42] Suryabrata (2004). Educational Psychology. Jakarta: Rajawali Pers.

[43] Suryana. 2013. Entrepreneurship Approach to Characteristics of Successful Entrepreneurs. Jakarta: Golden.

[44] Tjiptono, Fandy. (2005). Marketing Services. Malang: Bayumedia.

[45] Prastowo, Andi. (2012). Creative Guide to Making Innovative Teaching Materials. Yogyakarta: Yogya Press.

[46] Winkel. 2004. Educational Psychology and Learning Evaluation. Jakarta. PT.Gramedia Pustaka Utama.

[47] Winardi. 2003. Entrepreneur \& Entrepreneurship. Jakarta. Prenada Media.

[48] Zimmerer. 1996. Introduction to entrepreneurship and Small Management. Jakarta: PT. Gramedia Index.

[49] Christian, Samuel. 2017. The Influence of Family Environment, Entrepreneurship Education, and Self-Efficacy on Student Entrepreneurial Interest: Ciputra University Surabaya.

[50] Early, Agustian. 2018. The Influence of Family Environment, Knowledge, Entrepreneurship, Personality, and Motivation on Entrepreneurial Interest with Self Efficacy as a Moderating Variable.

[51] Harini, 2018. The Influence of Entrepreneurship Education and Self Efficacy on Entrepreneurial Interest (Study on the Economic Education Study Program, 2014-2016 Class): Sebelas Maret University.

[52] Lestari, Hasolan, and Minarsih. 2016. The Influence of Independent Attitude, Family Environment, and Motivation on Youth Entrepreneurial Interest (Empirical Study in Jamus Village, Mranggen District, Demark Regency). Journal Of Management, Vol. 2 Nommer 2. Accessed March 6, 2019.

[53] Pratiwi and Wardana (2016). The Influence of Internal and External Factors on Entrepreneurial Interest in Students of the Faculty of Economics and Business. Udayana University. E-journal of Management of Udayana University, 5 (8), 5125-5242.

[54] Pandowo, Merinda. 2017. The Influence Entrepreneurial Knowledge, Family Experience with Business Entrepreneurial Education On The Student Entrepreneurship in UKM SAM Ratulangi University: SAM Ratulangi University.

[55] Purnomo. 2005. Study on Foreign Investment in Indonesia. JuRNAL of Development Economics: Vol 6 Jakarta.

[56] Rainer Harms. 2015. The Impanct of Entrepreneurship Edducation On The Entrepreneurial Intention of Student in Science and Engineering versus Business Student University Programs: Business Student University Programs.

[57] Santoso, Sigit. 2013. The Influence of Self-Efficacy and Entrepreneurship Education on Entrepreneurial Interest in Student Entrepreneurship Education, Faculty of Economics, State University of Malang, 2013: State University of Malang. 
[58] Sintya, Ni Made. 2019. The Influence of Motivation, Self Efficacy, Income Expectations, Family Environment, and Entrepreneurship Education on Entrepreneurial Interest in Students of the Department of Accounting, Mahasaraswati University Denpasar: Mahasaraswati Denpasar University.

[59] Siti, Shoimah. 2019 The Influence of Self Efficacy, Family Environment and Entrepreneurship Education on Entrepreneurial Interest in Economics Faculty Students. Unisda Lamongan.

[60] Vendy. 2017. The Effect of Entrepreneurship Education on Entrepreneurial Intention of University Student by Adopting Linan Model: Bina Nusantara University.

[61] Suratno. 2019. The Analysis of the Effect of Entrepreneurship Education, Perceived Desirability, and Entrepreneurial Self-Efficacy on University Student Entrepreneurial Intention: University Student Entrepreneurial Intention.

[62] Subandono. 2017. The Effect of Entrepreneurship Education and Training Life Skill Learning on Entrepreneurship Interest. Essay. Semarang: University of Semarang.

[63] Sifrid. 2018. The Influence Of Entrepreneur Knowledge, Family Experience with Business, Entrepreneurial Education on the Interest of Student Entrepreneurship in UKM, SAM Ratulangi University: SAM Ratulangi University.

[64] Widaryanti. 2013. Analysis of Income Smoothing and Influencing Factors on Manufacturing Companies on the Indonesia Stock Exchange. Economic Focus. Vol 4 no 2 December 2009.

[65] Yildirm, Nihan. 208. Ready to Dare? A Case Study on The Entrepreneurial Intentions Of Business and Engineering Stdents in Turkey: Tureky. 